\title{
ANALISIS FAKTOR-FAKTOR PENENTU KEBERHASILAN KLASTER (STUDI PADA KLASTER PERTANIAN TERPADU KABUPATEN SUKOHARJO)
}

\author{
R. Kunto Adi, Moh. Harisudin dan Minar Ferichani \\ Program Studi Agribisnis Fakultas Pertanian UNS Surakarta \\ Email: kuntouns@gmail.com
}

\begin{abstract}
Center for Integrated Farming in Agribusiness Regency Sukoharjo is one of centers in the Sukoharjo Regency potential number of units SME's agribusiness, which has considerable potential to further developed forward. The research method is implemented with the survey and FGD (Focus Group Discussion). The results showed stakeholders performance within Integrated Agricultural Cluster development seen from the achievement of the results of the institutional activities that had been undertaken by related agencies involved in the Integrated Agriculture cluster development in Sukoharjo, Sukoharjo Regency FEDEP, among others, the Bappeda Sukoharjo Regency, local Government of Sukoharjo through service related, and Agricultural Cluster Integrated Rembug Forum as targets of mentoring activities during this FEDEP is enough well, though still not optimal. The role of BDS (Business Development Service) as escort agency nor an escort FEDEP Integrated Agricultural Cluster during this already plays well. The role of the College during this already good. While the role of financing institution has also been good, especially Banking as long as it's been good in support of cluster development in integrated agricultural. The role of the association profession and non government (NGO) in Sukoharjo Regency have already good much seen in Integrated Agriculture cluster development Sukoharjo Regency. Determinants of the success of the integrated Agriculture Cluster, among others, specialization, research and development capacity, knowledge and skills, human resource development, networking and social capital, proximity to suppliers, capital availability, the soul of entrepreneurship, as well as leadership and shared vision. Determinants of the success of the integrated Agriculture Cluster, among others, specialization, research and development capacity, knowledge and skills, human resource development, networking and social capital, proximity to suppliers, capital availability, the soul of entrepreneurship, as well as leadership and shared vision. Some of the determinants of the success of the cluster has been running quite well for example in terms of networking and social capital, proximity to suppliers, and the spirit of entrepreneurship, while other factors are still not running optimally. Suggestions in this study include 1). Capacity building of institutional FEDEP and Agricultural Integrated Cluster Forum Sukoharjo Regency, 2) upgrade human resource in Cluster of integrated Farming, with a wide range of training courses is gradually and continuously, intensively involved with the College and the state-owned enterprises as well as private owned companies, and 3). Network Development efforts on Integrated Agricultural Cluster through the integrated system between the sub cluster, through cooperation between the sub cluster associated with the provision of raw materials, production technology, product innovation, product quality standards (certification), institutional, and product marketing, with facilitation and mentoring of stakeholders associated within FEDEP Sukoharjo Regency. The expected synergies also intercity in SOLO RAYA.
\end{abstract}

Keywords: agribusiness, cluster, integrated agricultural, performance.

\section{PENDAHULUAN}

Pada era Otonomi Daerah, pengembangan UMKM terutama UMKM di sub sektor agribisnis diarahkan melalui konsep pengembangan UMKM Agribisnis melalui Pendekatan Klaster yang berorientasi pada Kemitraan Strategis Agribisnis, dengan pelibatan berbagai pihak baik pelaku usaha maupun pihak-pihak stakeholders. Oleh karena sebagian besar permasalahan pelaku UMKM secara umum maupun UMKM agribisnis dikarenakan rendahnya akses pelaku UMKM terhadap informasi dan teknologi, produksi, manajemen, pemasaran, dan sumber permodalan. Oleh karena itu perlu upaya strategis dan komprehensif dalam membangun dan memperkuat upaya pengembangan UMKM melalui Pendekatan Klaster yang berorientasi pada Perkuatan Kemitraan Strategis Agribisnis. 
Kabupaten Sukoharjo merupakan salah satu kabupaten di Provinsi Jawa Tengah yang mempunyai potensi jumlah unit UMKM agribisnis yang cukup besar, sebagaimana pada tabel 1.

Tabel 1. Jumlah Unit Usaha Pada UMKM Agribisnis Unggulan Pada Klaster Pertanian Terpadu di Kabupaten Sukoharjo Tahun 2012

\begin{tabular}{llc}
\hline No & \multicolumn{1}{c}{$\begin{array}{c}\text { Jenis Sentra } \\
\text { UMKM }\end{array}$} & $\begin{array}{c}\text { Jumlah Usaha } \\
\text { (unit) }\end{array}$ \\
\hline 1 & Peternakan Sapi & 65 \\
2 & Pertanian Organik & 175 \\
3 & Jamur & 35 \\
4 & Tahu & 41
\end{tabular}

Sumber : Profil Klaster Binaan FEDEP Kabupaten Sukoharjo (2013).

Berdasarkan data Bappeda Sukoharjo tahun 2013, terdapat 4 (empat) sentra agribisnis unggulan di Kabupaten Sukoharjo, yang mempunyai potensi cukup besar dari sisi ketersediaan bahan baku, jumlah unit usaha, ketersediaan dan kualitas produk serta potensi pasar. Pengembangan Klaster Pertanian Terpadu menjadi salah satu ikon komoditas unggulan di Kabupaten Sukoharjo. klaster di Kabupaten Sukoharjo". Dalam perkembangannya Klaster Pertanian Terpadu di Kabupaten Sukoharjo, kurang berjalan secara optimal, dapat dilihat dari kebersamaan dan komitmen anggota klaster, sehingga berdampak terhadap kinerja klaster secara keseluruhan. Tujuan yang akan dicapai dalam penelitian ini adalah : (1) Mengetahui kinerja Stakeholders Jejaring Kemitraan Agribisnis dalam Pengembangan Klaster Pertanian Terpadu Kabupaten Sukoharjo, dan (2) Mengetahui faktor-faktor penentu keberhasilan Klaster Pertanian Terpadu di Kabupaten Sukoharjo. Dengan mengetahui masalah-masalah yang dihadapi dalam pengembangan klaster, dan pada akhirnya dapat dijadikan sebagai pertimbangan dalam menyusun model dan rencana strategi serta rencana operasonal dalam pengembangan Klaster UMKM unggulan ke depan.

\section{METODE PENELITIAN}

Metode dasar yang digunakan dalam penelitian ini adalah metode deskriptif analitis, yakni penelitian yang didasarkan pada pemecahan masalah yang aktual yang ada pada masa sekarang dimana data yang ada mula- mula disusun, dijelaskan kemudian dianalisis (metode analitik), dengan menggunakan teknik survei, yaitu penelitian dengan mengambil sampel dari suatu populasi dengan menggunakan kuesioner sebagai alat pengumpul data yang kemudian ditabulasikan sebagai langkah awal untuk melakukan analisis data (Singarimbun, 1995).

Metode penentuan daerah penelitian dilakukan secara sengaja (purposive) yaitu cara pengambilan daerah penelitian dengan mempertimbangkan alasan yang diteliti dari daerah penelitian (Singarimbun, 1995). Penentuan lokasi penelitian secara purposive atau penentuan daerah yang didasarkan pada karakteristik atau pertimbangan tertentu yang relevan dengan permasalahan penelitian, dimana sebagai lokasi penelitian yaitu Kabupaten Sukoharjo, dengan pertimbangan :

a. Di wilayah Kabupaten Sukoharjo terdapat Klaster Pertanian Terpadu yang dibentuk pada tahun 2010 dan merupakan klaster unggulan, yang sampai sekarang masih eksis dalam melaksanakan usahanya, akan tetapi perannya selama ini belum optimal dan perlu ditingkatkan lagi ke depan.

b. Di wilayah Kabupaten Sukoharjo terdapat sentra-sentra UMKM agribisnis terkait lain unggulan yang jumlah unit usahanya cukup besar (tabel 1), dengan potensi pengembangan yang cukup besar ke depan.

Penelitian ini dilaksanakan dengan kegiatan survei, FGD, dan pencatatan (data sekunder), dengan pengumpulan data menggunakan daftar pertanyaan (kuesioner) secara terbuka, yang ditujukan kepada responden. Dalam penelitian ini digunakan teknik wawancara dan pencatatan, dan diskusi kelompok terbatas atau FGD (Focus Group Discussion), sehingga akan dapat diidentifikasi kebutuhan, masalah UMKM dan stakeholders terkait, dan upaya-upaya yang telah dan akan dilaksanakan dalam pengembangan Klaster Pertanian Terpadu di Kabupaten Sukoharjo.

Metode analisis data untuk mengetahui faktor-faktor keberhasilan Klaster Pertanian Terpadu di Kabupaten Sukoharjo dilaksanakan dengan metode kualitatif, dengan pembobotan dalam setiap aspek faktor penentu keberhasilan klaster, menggunakan analisis tabel. Analisis faktor-faktor penentu keberhasilan kekuatan klaster yang diteliti, meliputi aspek-aspek, yaitu : 1). Spesialisasi, 2). Kapasitas penelitian dan pengembangan, 3). Pengetahuan dan 
ketrampilan, 4). Pengembangan SDM, 5). Jaringan kerjasama dan modal sosial, 6). Kedekatan dengan pemasok, 7). Ketersediaan modal, 8). Jiwa kewirausahaan, dan 9). Kepemimpinan dan visi bersama (Bappenas, 2005).

\section{HASIL DAN PEMBAHASAN}

Kinerja Stakeholders Jejaring Kemitraan Agribisnis dalam Pengembangan Klaster Pertanian Terpadu

Kinerja FEDEP (Forum for Economic Development and Employment Promotion)

Kinerja kelembagaan FEDEP Kabupaten Sukoharjo dilihat dari pencapaian hasil kegiatan kelembagaan yang selama ini telah dilaksanakan oleh FEDEP Kabupaten Sukoharjo, yang meliputi :

\section{Partisipasi Stakeholders dalam FEDEP}

Selama ini partisipasi stakeholders dalam FEDEP yang meliputi beberapa unsur yang terkait dengan pengembangan Klaster Pertanian Terpadu di Kabupaten Sukoharjo, sudah cukup baik, dalam hal koordinasi antar instansi/lembaga yang semakin baik, yang dapat dilihat secara langsung dari tingkat kehadiran dan partisipasi langsung dalam bentuk program kegiatan yang semakin sinergi antar instansi/lembaga yang tergabung dalam FEDEP, sehingga tumpang tindih program kegiatan bisa diminimalisir. Hal tersebut dikarenakan sebagian besar stakeholders dalam merancang program kegiatan di instansi/lembaga masing-masing sudah disinkronkan dengan program kerja FEDEP, oleh karena setiap tahun ada kegiatan sinkronisasi program FEDEP di tingkat provinsi maupun kabupaten.

\section{Proses Manajemen FEDEP}

Proses manajemen dalam FEDEP sudah baik, yang meliputi proses perencanaan program FEDEP, implementasi program FEDEP, dan monitoring evaluasi program FEDEP. Dalam perencanaan program FEDEP sudah secara rutin dilaksanakan setiap akhir tahun, dengan melibatkan secara aktif stakeholders dalam FEDEP. Dalam implementasi program FEDEP juga sudah baik, terutama yang terkait dengan kegiatan FEDEP, melalui rapat-rapat koordinasi FEDEP, perkuatan kelembagaan FEDEP dan klaster UMKM, studi banding FEDEP dan Klaster
Pertanian Terpadu, pameran FEDEP dan Klaster Pertanian Terpadu, dan lain-lain, sudah sesuai dengan rencana program yang telah ditetapkan. Demikian juga dalam hal monitoring dan evaluasi program FEDEP juga sudah dilaksanakan dengan baik, misal monitoring dan evaluasi kegiatan pendampingan terhadap Klaster Pertanian Terpadu, penyusunan laporan FEDEP, penyusunan laporan/dokumen PEL, penyusunan laporan Business Plan Klaster Pertanian Terpadu, dan lain-lain.

3. Peran dan Dukungan Stakeholders dalam FEDEP

a. Peran dan Dukungan Pemda (BAPPEDA, Dinas Terkait)

Peran Bappeda Kabupaten Sukoharjo terhadap pengembangan FEDEP, antara lain melakukan penguatan kelembagaan Klaster Pertanian Terpadu (organisasi, kepengurusan, AD/ART), fasilitasi perencanaan kegiatan klaster/program kerja Klaster Pertanian Terpadu, dan fasilitasi dan koordinasi dengan Dinas terkait guna pengembangan Klaster Pertanian Terpadu, baik ditingkat daerah maupun tingkat vertikal. Keberadaan FEDEP sangat dibutuhkan oleh pemerintah daerah karena membantu menentukan prioritas yang sesuai dengan kebutuhan nyata di lapangan sehingga para pelaku ekonomi daerah bisa terlibat dalam program-program pemerintah.

Selain itu, peran dan dukungan Pemda meliputi peran dan dukungan Pemda Provinsi Jawa Tengah yaitu dalam hal fasilitasi pendampingan/ pembinaan FEDEP oleh BAPPEDA dan FPESD Provinsi Jawa Tengah, sedangkan peran dan dukungan Pemda Kabupaten Sukoharjo selama ini terkait dengan aspek kebijakan melalui kebijakan terkait legalisasi kelembagaan FEDEP dan Klaster Pertanian Terpadu (SK FEDEP dan SK Klaster Pertanian Terpadu), sedangkan melalui Dinas terkait yaitu dalam kegiatan pelatihanpelatihan yang selama ini sudah dilaksanakan oleh dinas terkait, misal Dinas Koperasi dan UKM, Dinas Perindustrian dan Perdagangan, Dinas Pertanian dan Peternakan, Badan Lingkungan Hidup, dan dinas terkait 
lain. Dukungan lain dalam hal pendanaan yaitu pengalokasian pendanaan untuk operasionalisasi kegiatan FEDEP dari Provinsi Jawa Tengah dan dana APBD Kabupaten Sukoharjo. Dukungan lain dalam hal berbagai peraturan tentang Koperasi dan UMKM, pemberian legalisasi/badan hukum bagi UMKM, dan berbagai kegiatan pendampingan, misal studi banding, promosi (pameran, leaflet), pelatihan, penyusunan program kerja Klaster Pertanian Terpadu, dan lain-lain.

Dukungan lain, misalnya dengan keluarnya Surat dari Bappeda Provinsi Jawa Tengah Nomor 500/2501 tanggal 31 Januari 2013 perihal Role Model Pengembangan Klaster menyebutkan bahwa sebagai tindak lanjut dari Rakor FPESD dan Stratifikasi Klaster, maka Klaster Pertanian Organik Kabupaten Sukoharjo ditunjuk sebagai Role Model, dan Bappeda Kabupaten Sukoharjo menindaklanjuti dengan mengirim surat kesiapan Klaster Pertanian Organik untuk difasilitasi oleh GIZ dan SKPD terkait sebagai Role Model Pengembangan Klaster dengan surat Nomor 005/553 tanggal 20 April 2013.

b. Peran dan Dukungan Lembaga/Instansi Mitra :

1) Peran Forum Rembug Klaster (FRK) Klaster Pertanian Terpadu

Peran Forum Rembug Klaster atau kelembagaan Klaster Pertanian Terpadu sebagai sasaran kegiatan pendampingan FEDEP selama ini sudah cukup baik, meskipun masih belum optimal. Peran dan dukungan Klaster Pertanian Terpadu tidak hanya sebagai obyek kegiatan pendampingan, tetapi menjadi subyek kegiatan pendampingan, yang tidak hanya tergantung pada program kegiatan yang telah ditetapkan, tetapi Klaster Pertanian Terpadu selama ini sudah lebih mandiri, misal dalam menyusun program kerja klaster setiap tahun, penguatan kelembagaan klaster, dan promosi (pameran).

2) Peran Pendamping UMKM (BDS)

$$
\text { Peran BDS Business }
$$

Development Service/Lembaga

Pengembangan Bisnis) Pusat Studi

Pendampingan Koperasi dan UMKM
LPPM Universitas Sebelas Maret (UNS) sebagai lembaga pendamping FEDEP maupun pendamping Klaster Pertanian Terpadu selama ini sudah berperan baik, dalam hal ini sebagai Pembina FEDEP dan Klaster Pertanian Terpadu, misal dalam pendampingan penguatan kelembagaan FEDEP dan Klaster Pertanian Terpadu, pelatihanpelatihan, penyusunan Business Plan Klaster Pertanian Terpadu, penyusunan dokumen PEL, fasilitasi promosi (pameran), introduksi teknologi, dan lain-lain.

3) Peran Perguruan Tinggi

Peran Perguruan Tinggi selama ini sudah baik, misalnya dalam hal pendampingan melalui Program Hibah Kompetisi DIKTI, IPTEKDA LIPI, Diknas Jateng, BPPT, dan lainlain, melalui kegiatan-kegiatan pelatihan dan atau introduksi Teknologi Tepat Guna (TTG) kepada Klaster Pertanian Terpadu dampingan FEDEP. Beberapa Perguruan Tinggi yang sudah aktif dalam pendampingan tersebut, misalnya Universitas Sebelas Maret (UNS), UNIVET, UNISRI, UMS, UTP, dan lain-lain.

4) Peran Lembaga Pembiayaan (Perbankan/Non Perbankan)

Peran lembaga pembiayaan sudah baik, terutama Perbankan selama ini sudah baik dalam mendukung pengembangan Klaster Pertanian Terpadu, meskipun tidak secara langsung membiayai kegiatan FEDEP, tetapi peran dan dukungan lembaga perbankan dalam membiayai kegiatan pendampingan kepada Klaster Pertanian Terpadu dampingan FEDEP Kabupaten Sukoharjo, misal Bank Jateng memberikan kredit bunga lunak (KKPE, Kredit Pembibitan Sapi) kepada peternak sapi, dan lain-lain. Demikian juga lembaga non perbankan, misalnya koperasi, BMT, juga sudah banyak memberikan kredit kepada UMKM Klaster Pertanian Terpadu dampingan FEDEP. 
5) Peran Asosiasi (KADIN, GAPENSI, JARPETO Kabupaten Sukoharjo) Peran asosiasi profesi di Kabupaten Sukoharjo sudah cukup banyak terlihat dalam pengembangan Klaster Pertanian Terpadu Kabupaten Sukoharjo, misal KADIN/GAPENSI dalam hal ketenagakerjaan, promosi produk Klaster Pertanian Terpadu, jejaring pasar, dan akses informasi bagi UMKM Klaster Pertanian Terpadu. Sedangkan peran JARPETO (Jaringan Petani Organik) Kabupaten Sukoharjo selama ini juga sudah banyak memberikan dukungan dalam memperkuat kelembagaan Klaster Pertanian Terpadu, dimana sebagian besar petani organik dan peternak merupakan anggota JARPETO Kabupaten Sukoharjo.

6) Peran LSM/NGo

Peran lembaga non pemerintah (NGO), misalnya GTZ-RED dalam pembentukan FEDEP Kabupaten Sukoharjo, dan GIZ mengadakan Pelatihan Bisnis di Desa Grogol, Kec. Weru pada tanggal 27 Mei 2013 dalam rangka pengembangan Desa Organik, di Kecamatan Weru, Kabupaten Sukoharjo, serta pada tanggal 8 Juli 2013 GIZ juga mengadakan pelatihan lanjutan bagi Klaster Pertanian Organik. Selama ini peran LSM belum banyak terlibat secara aktif dalam kegiatan FEDEP Kabupaten Sukoharjo.

\section{Faktor-faktor Penentu Keberhasilan Klaster Pertanian Terpadu}

\section{Spesialisasi}

Hasil penelitian menunjukkan bahwa klaster mempunyai spesialisasi bidang usaha tertentu, tergantung dari jenis dan variasi usaha yang dikelola klaster. Klaster juga memfasilitasi peningkatan spesialisasi keahlian anggota klaster, terutama keahlian yang terkait dengan usaha yang dikelola oleh anggota klaster. Sebagian besar anggota klaster menyatakan belum banyak fasilitasi yang dilakukan pihak lain untuk meningkatkan spesialisasi keahlian anggota klaster.

Hasil penelitian juga menunjukkan bahwa spesialisasi keahlian anggota klaster sangat bermanfaat sebagai modal untuk mengembangkan usaha yang dikelola anggota klaster maupun usaha yang dikelola kelompok klaster. Sebagian besar anggota klaster berharap spesialisasi keahlian anggota klaster semakin mampu ditingkatkan dengan inovasi baru sehingga semakin meningkatkan kinerja klaster ke depan. Oleh karena itu perlu adanya respon positif atau komitmen yang tinggi anggota klaster agar spesialisasi keahlian anggota klaster dapat ditingkatkan. Peran lembaga terkait dalam pengembangan spesialisasi keahlian anggota klaster sangat diperlukan antara lain dari Pemerintah Daerah melalui Dinas terkait dan Perguruan Tinggi. Sebagian besar anggota klaster menyatakan belum adanya dukungan dari pihak terkait dalam peningkatan spesialisasi keahlian anggota klaster.

2. Kapasitas Penelitian dan Pengembangan

Hasil penelitian menunjukkan bahwa klaster atau anggota klaster tidak melakukan penelitian dan pengembangan secara swadaya, masih tergantung pada fasilitasi dari pihak terkait, terutama Pemerintah Daerah. Demikian juga peran klaster itu sendiri dalam memfasilitasi peningkatan kemampuan penelitian dan pengembangan bagi anggota klaster belum banyak dilakukan.

Hasil penelitian juga menunjukkan bahwa pihak terkait belum banyak terlibat dalam memfasilitasi peningkatan kemampuan penelitian dan pengembangan bagi anggota klaster. Adapun harapan ke depan dari sebagian besar anggota klaster agar kemampuan penelitian dan pengembangan bagi anggota klaster semakin meningkat adalah dengan mencari jaringan kerjasama dengan pihak-pihak yang berpotensi mendukung penelitian dan pengembangan bagi klaster dan anggota klaster. Hal tersebut harus didukung oleh respon positif atau komitmen yang tinggi anggota klaster agar kemampuan penelitian dan pengembangan anggota klaster ke depan dapat ditingkatkan. Oleh karena itu peran Perguruan Tinggi diharapkan dapat mendukung upaya peningkatan kemampuan penelitian dan pengembangan bagi klaster dan anggota klaster ke depan. Adapun kendala yang dihadapi adalah terbatasnya akses kerjasama dengan pihak terkait. 
3. Pengetahuan dan Ketrampilan

Hasil penelitian menunjukkan bahwa sebagian besar anggota klaster mempunyai pengetahuan dan ketrampilan yang memadai, terutama terkait bidang usaha yang ditekuni. Beberapa klaster sudah memfasilitasi peningkatan pengetahuan dan ketrampilan bagi anggota klaster. Pihakpihak yang selama ini sudah memfasilitasi peningkatan pengetahuan dan ketrampilan adalah Pemerintah Daerah melalui dinas terkait, yang berupa pelatihan-pelatihan teknis produksi, manajemen, pemasaran, dan lain-lain. Sebagian besar anggota klaster merasakan manfaat dengan adanya fasilitasi peningkatan pengetahuan dan ketrampilan untuk mengembangkan usaha.

Hasil penelitian juga menunjukkan bahwa harapan sebagian besar anggota klaster agar pengetahuan dan ketrampilannya meningkat adalah dengan menjalin kerjasama dengan pihak terkait semakin ditingkatkan, terutama dengan Perguruan Tinggi dan pihak swasta. Oleh karena itu perlu respon positif atau komitmen yang tinggi dari anggota klaster agar pengetahuan dan ketrampilan anggota klasetr dapat ditingkatkan. Kendala yang dihadapi dalam peningkatan pengetahuan dan ketrampilan anggota klaster adalah kadang kala belum adanya contoh yang konkret sehingga pelaku usaha kurang bisa menerima ilmu dalam kegiatan penyuluhan atau pelatihan untuk dapat diterapkan.

4. Pengembangan SDM

Hasil penelitian menunjukkan bahwa kemampuan SDM anggota klaster sudah cukup memadai, terutama secara teknis produksi. Sebagian besar klaster sudah memfasilitasi upaya pengembangan SDM bagi anggota klaster melalui pelatihanpelatihan. Sedangkan pihak lain yang memfasilitasi kegiatan pelatihan adalah Pemerintah Daerah melalui dinas terkait. Kegiatan fasilitasi yang dilakukan oleh Pemda untuk mengembangkan SDM anggota klaster adalah berupa pelatihan. Manfaat pengembangan SDM bagi klaster atau anggota klaster adalah menambah ilmu dan ketrampilan anggota klaster.

Hasil penelitian juga menunjukkan bahwa harapan ke depan agar pengembangan SDM anggota klaster semakin meningkat adalah dengan respon positif atau komitmen yang tinggi dari anggota klaster dan semua pihak terkait, serta adanya dukungan peralatan produksi, sehingga mendukung upaya pengembangan SDM anggota klaster. Oleh karena itu perlu komitmen terutama anggota klaster dan koordinasi serta kerjasama yang baik dengan pihak terkait agar upaya pengembangan SDM bagi anggota klaster ke depan semakin meningkat. Adapun pihak-pihak yang diharapkan bisa mendukung pengembangan SDM bagi anggota klaster adalah Perguruan Tinggi dan pihak swasta. Kendala yang dihadapi adalah terbatasnya dukungan kerjasama dengan pihak terkait.

5. Jaringan kerjasama dan modal sosial

Hasil penelitian menunjukkan bahwa anggota klaster dan klaster mempunyai jaringan kerjasama dan modal sosial yang memadai, dalam bentuk pertukaran informasi, pengadaan sarana produksi, dan jual beli antar anggota klaster maupun dengan klaster lain. Klaster memfasilitasi jaringan kerjasama anggota klaster, dengan adanya kerjasama tersebut, hubungan antar anggota klaster akan semakin erat, dan organisasi klaster pun akan semakin kuat. Pihak-pihak lain yang menjalin kerjasama dengan klaster/anggota klaster antara lain Pemerintah Daerah melalui dinas terkait, pemasok dan Perguruan Tinggi. Fasilitasi yang diberikan pihak-pihak tersebut antara lain kemudahan akses bahan baku, pemasaran, dan pelatihan-pelatihan.

Sebagian besar anggota klaster merasakan manfaat kerjasama tersebut yaitu menambah jaringan usaha dan kemudahan akses. Harapan ke depan agar kerjasama semakin meningkat yaitu dengan mengintensifkan kerjasama sehingga dapat berjalan terus menerus, dan semakin banyak jaringan kerjasama yang dibentuk. Oleh karena itu yang perlu dipersiapkan adalah kepercayaan antar pihak baik antar anggota klaster, maupun pihak-pihak yang menjalin kerjasama dengan klaster/anggota klaster, selain itu juga komunikasi yang efektif antar anggota klaster maupun dengan pihak-pihak lain yang terkait, antara lain Pemerintah Daerah dan seluruh anggota klaster. Kendala yang dihadapi dalam meningkatkan kerjasama klaster adalah kesibukan setiap anggota klaster, belum adanya perhatian 
yang serius kepada pelaku usaha, dan tidak adanya jaringan kerjasama.

6. Kedekatan dengan pemasok

Hasil penelitian menunjukkan bahwa anggota klaster dan klaster mempunyai hubungan baik dengan pemasok, yaitu sebagai pelanggan sarana produksi yang dibutuhkan oleh pelaku usaha dan selama ini sudah terjalin kerjasama yang erat dan berkelanjutan. Klaster selama ini belum banyak memfasilitasi hubungan dengan pemasok bagi anggota klaster, hubungan dengan pemasok masih dilaksanakan secara mandiri atau swadaya anggota klaster sendiri. Meskipun ada juga anggota klaster yang atas inisiatif kelompok mengkoordinir suplai bahan baku kepada anggota klaster lain. Belum ada pihak-pihak lain yang memfasilitasi hubungan dengan pemasok bagi klaster maupun anggota klaster. Manfaat dengan adanya hubungan baik dengan pemasok adalah kemudahan memperoleh bahan baku dan menambah jaringan usaha.

Harapan ke depan agar hubungan dengan pemasok semakin baik yaitu dengan adanya dukungan dari klaster dan anggota klaster dalam menjalin hubungan secara intensif dan menjaga kepercayaan pemasok. Oleh karena itu perlu adanya keaktifan anggota klaster dan rasa saling percaya antar anggota klaster maupun pemasok yang selama ini menjadi pemasok bagi klaster maupun anggota klaster. Pihak-pihak yang diharapkan mendukung agar hubungan dengan pemasok semakin baik ke depan adalah semua anggota klaster dan Pemerintah Daerah. Kendala yang dihadapi adalah permodalan dan hubungan kerjasama dengan pemasok masih terbatas.

\section{Ketersediaan modal}

Hasil penelitian menunjukkan bahwa anggota klaster dan klaster mempunyai ketersediaan modal yang cukup memadai yang disediakan dari modal sendiri, meskipun ada beberapa anggota klaster yang masih kekurangan modal, sehingga harus mengajukan pinjaman ke bank. Klaster selama ini tidak memfasilitasi penyediaan modal bagi anggota klaster, karena keterbatasan dana yang dimiliki oleh klaster, akan tetapi beberapa klaster memfasilitasi dengan memberikan informasi kepada anggota klaster terkait sumber-sumber pembiayaan dari pihak lain, misalnya bank, hibah, CSR-PKBL, dan lainlain. Pihak-pihak yang selama ini memfasilitasi penyediaan modal yaitu bank dan dinas, melalui fasilitasi pinjaman modal atau hibah kepada anggota klaster. Manfaat dengan adanya penyediaan modal tersebut bagi anggota klaster adalah memudahkan pemenuhan kebutuhan klaster, meningkatkan kemampuan usaha, pengembangan usaha, dan peningkatan produksi.

Harapan ke depan agar penyediaan modal bagi klaster/anggota klaster semakin meningkat adalah adanya dukungan dari berbagai pihak, dibentuknya koperasi usaha, fasilitasi pemberian kredit usaha bunga lunak, dan bantuan permodalan dari kerjasama dengan pihak lain, dan penciptaan unit usaha bagi klaster, sehingga permodalan klaster tidak hanya tergantung dari pinjaman tetapi juga bisa membiayai operasional kegiatan klaster dan anggota klaster dari unit usaha yang dikelola klaster tersebut. Oleh karena itu perlu kerjasama antar anggota klaster, adanya iuran anggota klaster untuk memupuk kas klaster, dan kerjasama dengan pihak lain penyedia modal. Pihak-pihak yang diharapkan mendukung agar penyediaan modal bagi klaster/anggota klaster semakin meningkat ke depan adalah seluruh anggota klaster, Pemerintah Daerah, dan pihak swasta, bank, dan perusahaan dengan dana CSR-PKBL. Kendala yang dihadapi adalah tidak ada rekomendasi dalam peminjaman modal harus diajukan ke pihak-pihak mana saja, tingkat kemampuan ekonomi anggota klaster yang berbeda, modal usaha digunakan untuk menutup produksi, dan bunga pinjaman masih tinggi.

8. Jiwa kewirausahaan

Hasil penelitian menunjukkan bahwa anggota klaster dan klaster mempunyai jiwa kewirausahaan yang baik, yaitu mempunyai inisiatif, berani mengambil risiko, kemandirian, tanggung jawab, dan komitmen pada usaha, serta selalu ingin maju. Klaster memfasilitasi upaya pengembangan jiwa kewirausahaan melalui motivasi usaha setiap ada pertemuan anggota klaster minimal setiap 4 (empat) bulan sekali. Pihak lain yang memfasilitasi upaya upaya pengembangan jiwa 
kewirausahaan yaitu Pemerintah Daerah melalui dinas terkait dengan pemberian materi kewirausahaan dan motivasi usaha serta penguatan kelembagaan klaster, dengan fasilitasi kegiatan penyuluhan dan pelatihan motivasi usaha. Manfaat dengan adanya upaya pengembangan jiwa kewirausahaan adalah menambah semangat berusaha anggota klaster untuk lebih berkembang dalam menjalankan usahanya. Selain itu juga semakin memperkuat kerjasama diantara anggota klaster, kebersamaan dan kekompakan anggota klaster.

Harapan ke depan agar jiwa kewirausahaan anggota klaster dan klaster semakin meningkat ke depan adalah dengan adanya bantuan pihak lain dalam menumbuhkan jiwa kewirausahaan secara kontinyu dan terus menerus, motivasi usaha semakin meningkiat, minat anggota untuk fokus dalam berwirausaha, dan meneruskan usaha dan regenerasi pelaku usaha. Oleh karena itu perlu kepercayaan diri anggota klaster untuk maju dan berkembang, komitmen anggota klaster, untuk selalu mengikuti fasilitasi pelatihan atau penyuluhan yang diberikan pihak terkait. Pihak-pihak yang diharapkan bisa mendukung yaitu Pemerintah Daerah melalui dinas terkait, dan Perguruan Tinggi. Kendala yang dihadapi adalah modal untuk mengadakan pelatihan dan penyuluhan terutama yang difasilitasi oleh klaster, keseriusan anggota klaster dalam mengikuti pelatihan/penyuluhan, pendidikan dan pengetahuan anggota klaster yang masih kurang memadai, serta dukungan dari pihak lain yang masih minim sehingga menyurutkan motivasi usaha.

9. Kepemimpinan dan visi bersama

Hasil penelitian menunjukkan bahwa kepemimpinan dalam klaster sudah cukup baik, dimana koordinasi pengurus klaster dengan anggota klaster sudah berjalan cukup baik, kemudian koordinasi antar anggota klaster juga sudah cukup baik, kepedulian terhadap anggota dan sesama anggota, karena selalu diadakan pertemuan rutin setiap 4 (empat) bulan sekali. Meskipun ada beberapa anggota klaster yang mengganggap dengan adanya klaster belum signifikan merasakan manfaatnya. Anggota klaster mempunyai visi bersama dalam memajukan klaster. Klaster selama ini belum berperan secara signifikan dalam pengembangan kepemimpinan dan visi bersama kepada anggota klaster, meskipun upaya tersebut selalu dilakukan setiap pertemuan klaster. Pihak lain yang sudah memberikan fasilitasi dalam pengembangan kepemimpinan dan visi bersama kepada anggota klaster, adalah Pemerintah Daerah melalui Bappeda dan dinas terkait dalam kegiatan penguatan klaster. Manfaat yang dirasakan oleh anggota klaster adalah kegiatan organisasi klaster menjadi semakin lancar/baik, tujuan klaster lebih jelas sehingga klaster dapat berjalan dengan baik, kesadaran akan tujuan bersama, serta menyamakan persepsi dan semangat untuk maju bersama.

Harapan ke depan agar kepemimpinan dan visi bersama anggota klaster semakin meningkat adalah peningkatan kualitas SDM, pemimpin klaster diharapkan semakin dapat mengayomi anggota klaster, lebih bertanggung jawab sebagai pemimpin, penentuan visi bersama klaster, klaster mampu dipimpin oleh orang yang kompeten dan memberikan manfaat yang lebih bagi anggotanya. Oleh karena itu perlu adalah adanya pertemuan rutin untuk membahas visi-visi bersama, pengetahuan dan ketrampilan yang memadai, dan memberikan kesempatan kepada anggota klaster untuk memimpin organisasi klaster. Pihak-pihak yang diharapkan mendukung adalah anggota klaster dan Pemerintah Daerah melalui dinas terkait dan Perguruan Tinggi. Kendala yang dihadapi adalah adanya perbedaan pendapat antar anggota klaster, sedikit anggota yang berani memimpin organisasi klaster, belum adanya koordinasi yang baik di dalam klaster, dan kesibukan dari setiap anggota klaster dengan usahanya masing-masing sehingga belum ada upaya pertemuan rutin yang khusus membahas visi bersama klaster.

\section{KESIMPULAN}

\section{Kesimpulan}

Kinerja stakeholders jejaring kemitraan agribisnis dalam pengembangan Klaster Pertanian Terpadu dilihat dari pencapaian hasil kegiatan kelembagaan yang selama ini telah dilaksanakan oleh lembaga-lembaga terkait yang terlibat dalam pengembangan Klaster 
Pertanian Terpadu di Kabupaten Sukoharjo, antara lain FEDEP Kabupaten Sukoharjo, Bappeda Kabupaten Sukoharjo, Pemda Sukoharjo melalui dinas terkait, dan Forum Rembug Klaster Pertanian Terpadu sebagai sasaran kegiatan pendampingan FEDEP selama ini sudah cukup baik, meskipun masih belum optimal. Peran BDS (Business Development Service/Lembaga Pengembangan Bisnis) sebagai lembaga pendamping FEDEP maupun pendamping Klaster Pertanian Terpadu selama ini sudah berperan baik. Peran Perguruan Tinggi selama ini sudah baik. Sedangkan peran lembaga pembiayaan juga sudah baik, terutama Perbankan selama ini sudah baik dalam mendukung pengembangan Klaster Pertanian Terpadu, meskipun tidak secara langsung membiayai kegiatan FEDEP, tetapi peran dan dukungan lembaga perbankan dalam membiayai kegiatan pendampingan kepada Klaster Pertanian Terpadu dampingan FEDEP Kabupaten Sukoharjo. Peran asosiasi profesi dan lembaga non pemerintah (NGO) di Kabupaten Sukoharjo sudah cukup banyak terlihat dalam pengembangan Klaster Pertanian Terpadu Kabupaten Sukoharjo, misal KADIN/GAPENSI dalam hal ketenagakerjaan, promosi produk Klaster Pertanian Terpadu, jejaring pasar, dan akses informasi bagi UMKM Klaster Pertanian Terpadu.

Faktor-faktor penentu keberhasilan Klaster Pertanian Terpadu antara lain spesialisasi, kapasitas penelitian dan pengembangan, pengetahuan dan ketrampilan, pengembangan SDM, jaringan kerjasama dan modal sosial, kedekatan dengan pemasok, ketersediaan modal, jiwa kewirausahaan, serta kepemimpinan dan visi bersama. Beberapa faktor penentu keberhasilan klaster sudah berjalan dengan cukup baik misalnya dalam hal jaringan kerjasama dan modal sosial, kedekatan dengan pemasok, dan jiwa kewirausahaan, sedangkan faktor-faktor lain masih belum berjalan secara optimal.

\section{Saran}

Perkuatan kelembagaan (Capacity Building) FEDEP dan Forum Rembug Klaster Pertanian Terpadu Kabupaten Sukoharjo, dengan lebih mengoptimalkan forum dialog secara lebih intensif dan partisipatif, dengan pelibatan para pemangku kepentingan/stakeholders terkait dengan pengembangan Klaster Pertanian Terpadu, sehingga pengembangan klaster lebih terkoordinasi dengan baik, terkait dengan kebijakan pengembangan klaster antar SKPD terkait; perencanaan, implementasi dan evaluasi program kerja Klaster Pertanian Terpadu di Kabupaten Sukoharjo.

Peningkatan kemampuan SDM Klaster Pertanian Terpadu, melalui pelatihan-pelatihan teknologi produksi dan teknik budidaya organik, manajemen usaha (manajemen keuangan, pemasaran), teknologi pengolahan pangan organik, dan teknologi informasi, dengan berbagai program pelatihan secara bertahap dan berkesinambungan, dengan melibatkan secara intensif Perguruan Tinggi dan pihak BUMN/BUMD serta swasta, melalui Program CSR/PKBL- BUMN, perbankan umum, lembaga keuangan daerah, koperasi, lembaga donor internasional, penjaminan kredit bagi UMKM, serta fasilitasi subsidi bunga dari sumber APBD kepada UMKM yang prospektif, serta mengoptimalkan perusahaan daerah (Perusda) melalui kemitraan dengan pelaku UMKM Klaster Pertanian Terpadu.

Pengembangan jaringan usaha pada Klaster Pertanian Terpadu : sub klaster pertanian organik, jamur, ternak sapi, jamu dan makanan olahan), melalui integrated system antar sub klaster, melalui kerjasama antar sub klaster terkait dengan penyediaan bahan baku, teknologi produksi, inovasi produk, standar kualitas produk (sertifikasi), kelembagaan, dan pemasaran produk, dengan fasilitasi dan pendampingan dari stakeholders terkait dalam FEDEP Kabupaten Sukoharjo, melalui sinergi kemitraan strategis antar dinas terkait dan stakeholders terkait lain (Perguruan Tinggi, Perbankan, dunia usaha/UMKM, koperasi, Lembaga Keuangan Mikro, Lembaga Swadaya Masyarakat, Asosiasi, Swasta/BUMN (CSR/LPDB/PKBL), Lembaga Donor Internasional, dan lain-lain). Sinergi tersebut diharapkan juga antar wilayah se-SOLO RAYA.

\section{DAFTAR PUSTAKA}

Bappenas. 2004. Kajian Strategis Pengembangan Kawasan Dalam Rangka Mendukung Akselerasi Peningkatan Daya Saing Daerah : Studi Kasus di Kelompok Industri Rotan-Cirebon, Logam-Tegal, dan Batik-Pekalongan. Direktorat Pengembangan Kawasan Khusus dan Tertinggal. BAPPENAS. Jakarta. 
Bappenas. 2005. Panduan Pembangunan Klaster Industri Untuk Pengembangan Ekonomi Daerah Berdaya Saing Tinggi. Direktorat Pengembangan Kawasan Khusus dan Tertinggal BAPPENAS. Jakarta.

Bungin, Burhan. 2003. Analisis Data Penelitian Kualitatif. Pemahaman Filosofis dan Metodologis ke Arah Penguasaan Model Aplikasi. Raja Grafindo Persada. Jakarta.
Dinas Perindustrian. 2008. Kebijakan Pengembangan Klaster Industri Jawa Tengah. Makalah. Dinas Perindustrian Provinsi Jawa Tengah. Semarang.

Singarimbun, M. 1995. Metode Penelitian Survei. LP3ES. Jakarta.

Soetrisno, Noer. 2003. Strategi Penguatan UKM Melalui Pendekatan Klaster Bisnis : Konsep, Pengalaman Empiris dan Harapan. Lutfansah Mediatama. Surabaya 